\title{
Perkembangan dan Efektivitas Pelaksanaan Pengawasan Pengelolaan Dana Desa pada Inspektorat Daerah Kabupaten Batang Hari
}

\author{
Jasasila \\ STIE Graha Karya Muara Bulian \\ Correspondence email: jasasila@yahoo.co.id
}

\begin{abstract}
The problem of this research is How the Development and Effectiveness of the Implementation of Village Fund Management in the Batang Hari District Inspectorate, with the aim of the research 1) To Know the Procedure of the Implementation of Village Fund Supervision carried out by the Batanghari Kabuaten Inspectorate 2) To Know the Development Findings of the Implementation of Village Fund Management Supervision in the Batang Hari Regency Inspectorate 3) To find out the level of effectiveness of the Implementation of Village Fund Management Supervision at the Batang Hari District Inspectorate. The type of data used in this study is a collection of information or facts that are recorded through direct observation while the data used is sourced from related agencies that are related to the research topic, the procedure for implementing the supervision of the writer is descriptive according to the data obtained, the authors also carry out an analysis using developmental analysis and effectiveness analysis. From the results of the analysis it was found that the greatest development of findings in 2017 was an increase of $6.81 \%$ from the findings of the previous year then in 2016 and 2017 there was a significant decrease which was down by $51.92 \%$ (2016) and in the year down 39, 37\% from the previous year generally showed that the findings of the Village Fund in Batang Hari Regency during 2013 - 2017 tended to decrease, meaning that the supervision carried out by the Inspectorate of the Batang Hari Regency was already good. The implementation of Village Fund Supervision conducted by the Inspectorate on average during 2013-2017 shows that the achievement is quite effective with an effective ratio of 69.57\%. Keywords: Procedure, Monitoring, Development, Effectiveness
\end{abstract}

Keyword: Effectiveness, Implementation, Fund Management

\section{PENDAHULUAN}

Undang-undang Nomor 6 Tahun 2014 menyebutkan bahwa Desa merupakan kesatuan masyarakat hukum yang memiliki batas wilayah yang berewenang untuk mengatur dan mengurus urusan pemerintahan, kepentingan masyarakat setempat berdasarkan prakarsa masyarakat, hak asal usul desa dan atau hak tradisional yang diakui dan dihormati dalam Sistem Pemerintahan NKRI. Desa dibentuk dengan tujuan untuk: Pemerintahan Desa yang profesional, efisien dan efektif, terbuka, serta bertanggung jawab; Meningkatkan pelayanan publik bagi warga masyarakat Desa guna mempercepat perwujudan dan kesejahteraan umum; Meningkatkan ketahanan sosial budaya masyarakat Desa guna mewujudkan masyarakat Desa yang mampu memelihara kesatuan sosial sebagai bagian dari ketahanan nasional; Memajukan perekonomian masyarakat Desa serta mengatasi kesenjangan pembangunan nasional; dan Memperkuat masyarakat Desa sebagai subjek pembangunan. Dalam rangka mencapai tujuan diatas perlu dibangun sistem pengelolaan keuangan yang baik.Potensi kecurangan pengelolaan dana desa perlu diantisipasi melalui pengawasan salah satunya oleh inspektorat, Sesuai dengan pasal 4 huruf (d) Permendagri No. 71 tahun 2015 bahwa pengawasan dilaksanakan oleh Pejabat Pengawas Pemerintah pada Inspektorat Kabupaten. Pengawasan pada hakekatnya merupakan ruang lingkup yang meliputi pengawasan internal dan pengawasan eksternal, Setiap perubahan terkait dengan ruang lingkup pengawasan keuangan negara melainkan hanya tertuju pada substansi pertanggungjawaban keuangan negara. Misalnya, lembaga yang berwenang melakukan pemeriksaan keuangan , bentuk pengawasan dalam rangka pengelolaan dan tanggung jawab keuangan negara dapat berupa pengawasan yang dilakukan oleh inspektorat jendral, inspektorat provinsi, dan inspektorat kabupaten/kota. Konsep pengawasan dalam hukum keuangan negara tertuju pada pengelolaan dan tanggungjawab keuangan negara dalam jangka waktu tertentu sesuai dengan jangka itu dapat diketahui bahwa pengelolaan dan tanggung jawab keuangan negara telah atau belum tercapai sasaran untuk menunjang fungsi negara sebagaimna termaktub dalam alinea keempat pembukaan UUD 1945. 2 Lembaga pemerintah, fungsi pengawasan merupakan tugas dan tanggung jawab seorang kepala pemerintahan, seperti di lingkup pemerintah provinsi merupakan tugas dan tanggung jawab gubernur sedangkan di pemerintah kabupaten dan kota merupakan tugas dan tanggung jawab bupati dan walikota. Namun karena katerbatasan kemampuan seseorang, yang berwenang melakukan pengawasan keuangan negara yang berada dibawah pemerintah tujuan diadakannya inspektorat jendral secara fungsional melaksanakan pengawasan intern terhadap pengelolan keuangan negara pada suatu instansi pemerintah baik ditingkat pusat maupun daerah yang bertanggung jawab terhadap menteri/pimpinan lembaga.

Tugas Pengawasan yang dilakukan inspektorat wilayah propinsi fungsinya melakukan pemeriksaan terhadap setiap unsur dan atau instansi di lingkungan pemerintah kabupaten/kota meliputi bidang-bidang pembinaan sosial 
politik, pembinaan pemerintah umum, pembinaan pemerintah desa pembinaan otonomi daerah, pembangunan, pembangunan desa, administrasi, organisasi dan ketatalaksanaan, kepegawaian, keuangan, pengujian serta penilaian atas hasil laporan berkala, pengusutan mengenai kebenaran laporan atau pengaduan tentang hambatan penyimpangan atau penyalahgunaan termasuk pembangunan desa karena pembangunan tersebut memperoleh pembiayaan dari anggaran pendapatan dan belanja negara, dari anggaran dan pembelanjaan tersebut yang dananya dialihkan ke pembangunan desa maka harus ada sebuah instansi pengawas agar pembangunan tersebut berjalan sesuai dengan rencana dan anggaran yang telah di ajukan, serta pengawasan tersebut untuk menghindari praktik korupsi atau penyalahgunaan dana desa. Maksud pengawasan itu dalam rumusan yang sederhana adalah untuk memahami dan menemukan apa yang salah demi perbaikan di masa mendatang. Sedangkan tujuan pengawasan itu adalah untuk meningkatkan pendayagunaan aparatur negara dalam melaksanakan tugas-tugas umum pemerintahan dan pembangunan menuju terwujudnya pemerintahan yang baik dan bersih (good and clean government) Seiring dengan semakin kuatnya tuntutan dorongan arus reformasi ditambah lagi dengan semakin kritisnya masyarakat dewasa ini, maka rumusan pengawasan yang sederhana itu tidaklah cukup dan masyarakat mengharapkan lebih dari sekedar memperbaiki atau mengoreksi kesalahan untuk perbaikan dimasa datang, melainkan terhadap kesalahan, kekeliruan apalagi penyelewengan yang telah terjadi tidak hanya sekedar dikoreksi dan diperbaiki akan tetapi harus diminta pertanggungjawaban kepada yang bersalah. Potensi masalah yang akan muncul dengan adanya ketidakselarasan ini adalah adanya tindakan kecurangan di Pemerintah Desa yang cukup tinggi. Kecurangan (fraud) adalah perbuatan curang yang dilakukan dengan berbagai cara secara licik dan bersifat menipu dan sering tidak disadari oleh korban yang dirugikan. Ada tiga jenis fraud yakni penyalahgunaan dana desa, kecurangan laporan keuangan dan korupsi. Kecurangan laporan keuangan nampak pada penyajiaan laporan keuangan (laporan APBDesa) yang dimanipulasi sehingga tidak mencerminkan kondisi yang sebenarnya.

Potensi kecurangan pengelolaan dana desa ini, perlu diantisipasi, dikendalikan melalui struktur dan sistem serta dicegah sehingga penggunaan dana desa dapat dimanfaatkan untuk kepentingan masyarakat desa secara keseluruhan. Seluruh instansi seharusnya bersama-sama bersinergi dalam rangka pengendalian dan pengawasan dana di Desa, baik Pemerintah Desa, Pemerintah Kecamatan, Pendamping Desa dan Pemerintah Kabupaten. Pengelolaan Keuangan Desa adalah keseluruhan kegiatan yang meliputi perencanaan, pelaksanaan, penatausahaan, pelaporan dan pertanggungjawaban keuangan desa. Pengelolaan keuangan desa, pada dasarnya dilaksanakan untuk mewujudkan desa sebagai suatu pemerintahan terdepan dan terdekat dengan rakyat, yang kuat, maju, mandiri, dan demokratis, hingga mampu melaksanakan penyelenggaraan pemerintahan dan pembangunan menuju masyarakat adil, makmur, dan sejahtera. Sebuah tujuan yang mulia, semulia peran APIP untuk menjaganya agar pengelolaan keuangan desa hingga dapat mewujudkan cita-cita tersebut. Salah satu pendekatan pengawasan yang dapat dilakukan oleh APIP adalah dengan melihat risiko-risiko yang dapat menghambat pencapaian tujuan pengelolaan dana tersebut. APIP harus memperhatikan seberapa tinggi tingkat risiko itu, setelah itu mengaitkan dengan pengendalian intern yang ada untuk mengantisipasinya. Semakin tinggi tingkat risikonya, maka langkah kerja pengawasan oleh APIP akan semakin rinci dan banyak. Jika kita cermati proses bisnis pengelolaan keuangan desa dan pengalaman beberapa tahun ini, kita dapat identifikasikan beberapa risiko, baik risiko tingkat entitas pemerintah desa, maupun risiko tingkat aktivitasnya. Risikorisiko itu dapat dikategorikan sebagai risiko bisnis dan risiko kecurangan (fraud). Risiko Keuangan Desa Tingkat Entitas Beberapa Risiko yang dapat terjadi dalam pengelolaan keuangan desa tingkat entitas pemerintahan desa antara lain Program dan Kegiatan pada RPJMDes, RKPDes, dan APB Des tidak sesuai aspirasi/kebutuhan masyarakat desa, kegagalan menyelenggarakan siklus pengelolaan keuangan desa yang sehat, kegagalan atau keterlambatan penyusunan laporan penyelenggaraan pemerintah desa, termasuk laporan pertanggungjawaban realisasi pelaksanaan apbdes, serta pengelolaan aset desa yang tidak efisien dan efektif. Esensi penguatan pengelolaan keuangan desa bertumpu pada beberapa unsur yakni: Asas Pengelolaan Keuangan Desa Keuangan Desa harus dikelola secara Transparan, akuntabel, partisipatif, tertib, disiplin anggaran, Kekuasaan Pengelolaan Keuangan Desa Pihak yang mempunyai kewenangan dalam pengelolaan keuangan desa yakni antara lain: Kepala Desa pemegang kekuasaan pengelolaan keuangan desa dan mewakili dalam kepemilikian kekayanan desa yang dipisahkan: Pejabat Teknis Pengelolaan Kuangan Desa (PTPKD). Struktur APBDesa yang memadai Struktur APBDesa terdiri dari pendapatan desa, belanja desa dan pembiayaan desa yang mencerminkan kondisi dan kebutuhan desa yang sebenarnya.Pengelolaan Keuangan Desa yang akuntabel Pengelolaan yang akuntabel harus dimulai dari perencanaan, pelaksanaan, penatausahaan, pelaporan sampai dengan proses pertanggungjawaban, Pembinaan dan Pengawasan Pembinaan dilakukan oleh Bupati beserta perangkat daerah dibawahnya. Pengawasan aset desa dalam konteks pengawasan pengelolaan keuangan desa, beberapa pihak yang bersama-sama bersinergi dalam rangka melakukan pengawasan pengelolaan keuangan desa diantaranya yakni: Masyarakat, Masyarakat mempunyai peran terbesar dalam pengawasan pengelolaan keuangan desa yakni Pemantauan Pelaksanaan pembangunan desa dan penyelenggaraan Pemerintahan Desa; BPD, BPD sebagai wakil masyarakat tingkat desa berperan dalam konteks pengawasan kinerja Kepala Desa sebagaimana diamanatkan dalam UndangUnadAng Nomor 6 Tahun 2014 tentang Desa Pasal 55; Camat mendapat limpahan wewenang dari Bupati untuk 
melakukan melakukan pembinaan dan pengawasan pengelolaan keuangan desa. Selain itu camat dapat berperan dalam fasilitasi pengelolaan keuangan Desa dan pendayagunaan aset Desa; Inspektorat Kabupaten Sesuai dengan UndangUndang Nomor 6 Tahun 2014 tentang Desa disebutkan secara tegas bahwa Pemerintah Kabupaten yang dalam hal ini Inspektorat berperan mengawasi pengelolaan keuangan desa dan pendayagunaan aset desa. Selain itu inspektorat berperan juga dengan melakukan pembinaan dan pengawasan Penyelenggaraan Pemerintahan Desa. Wewenang ini diperkuat dengan Peraturan Menteri Dalam Negeri Nomor 113 Tahun 2014 tentang Pengelolaan Keuangan Desa pasal 44 Ayat (2).

Tujuan penelitian ini adalah (1) untuk Mengetahui Prosedur Pelaksanaan Pengawasan Dana Desa yang dilakukan oleh Inspektorat Kabupaten Batang Hari; (2) untuk Mengetahui Perkembangan Temuan Pelaksanaan Pengawasan Pengelolaan Dana Desa pada Inspektorat Kabupaten Batang Hari; dan (3) untuk Mengetahui tingkat efektivitas Pelaksanaan Pengawasan Pengelolaan Dana Desa pada Inspektorat Kabupaten Batang Hari.

\section{METODE}

Data yang digunakan dalam penelitian ini adalah data runtut waktu (time series) yaitu data berkala yang dikumpulkan dari waktu ke waktu dalam penelitian ini data meliputi data tindak lanjut pengawasan selama periode 2013 - 2017, sedangkan metode analisa yang digunakan dalam penelitian ini adalah metode Deskriptif Kuantitatif, dimana dari hasil pengumpulan data diklarifikasi dan diidentifikasikan kemudian dianalisis sesuai dengan analisa data yang dilakukan secara berkelompok dan menyeleksi dari penelitian yang dilakukan dilapangan menurut kualitas dan kebenarannya sehingga memperoleh jawaban atas permasalahan yang diajukan. Alat analisa yang digunakan dalam penelitian ini adalah : untuk menjawab tujuan pertama dilakukan interprestasi terhadap skema prosedur pelaksanaan pengawasan yang dilakukan oleh Inspektorat Kabupaten Batanghari, sedangkan untuk menjawab tujuan kedua yang berhubungan dengan Perekembangan Temuan Pelaksanaan Pengawasan Pengelolaan Dana Desa maka dibuat Formulasi dengan rumus :

Perkembangan $=\frac{T_{n-T_{n-1}}}{T_{n-1}} \times 100 \%$

Dimana: $\mathrm{T}_{\mathrm{n}}=$ Temuan Tahun Analisis; $\mathrm{T}_{\mathrm{n}-1}=$ Temuan Sebelum Tahun Analisis

Untuk menjawab tujuan ketiga yaitu efektivitas Pelaksanaan Pengawasan maka formulasi yang digunakan adalah :

Efektifitas $=\frac{T L}{T} \times 100 \%$

Dimana: $\mathrm{T}=$ Temuan $($ Target $) ; \mathrm{TL}=$ Tindak Lanjut $($ realisasi $)$

Tabel 1

Tingkat Capaian Efektifitas

\begin{tabular}{rrr}
\hline & Rasio Efektivitas & Tingkat Capaian \\
\hline $\mathrm{x}<39,9$ & & Sangat Tidak Efektif \\
$40<\mathrm{x}<59,99$ & & Tidak Efektif \\
$60<\mathrm{x}<79,9$ & & Cukup Efektif \\
$80<\mathrm{x}$ & & Sangat Efektif \\
\hline
\end{tabular}

Sumber: Litbang Depdagri

\section{HASIL}

\section{Prosedur Pelaksanaan Pengawasan Dana Desa yang dilakukan oleh Inspektorat Kabupaten Batang Hari}

Salah satu instansi yang memiliki kewenangan dalam melakukan pengawasan terhadddap penyelenggara Pemerintahan Daerah adalah Kantor Inspektorat, dimana fungsi dan peran kantor Inspektorat adalah perencanaan program pengawasan, perumusan kebijakan dan fasilitasi pengawasan, pelasaksanaan pengawasan dan lain-lain. Inspektorat Kabupaten Batang Hari melakukan pengawasan secara berkala yang dilaksanakan setiap tahun terhadap semua satuan Organisasi Perangkat Daerah mulai dari Dinas, Badan, Kecamatan samapai ketingkat Desa/Kelurahan. Dalam pelaksanaan pengawasan terhadap perangkat Pemerintah Daerah Kantor Inspektorat Kabupaten Batang Hari mempunyai Prosedur Pelaksanan Pengawasan, dapat dilihat pada gambar dibawah ini : 
Gambar 1

Prosedur Pelaksanaan Pengawasan Dana Desa yang dilakukan oleh Inspektorat Kabupaten Batang Hari

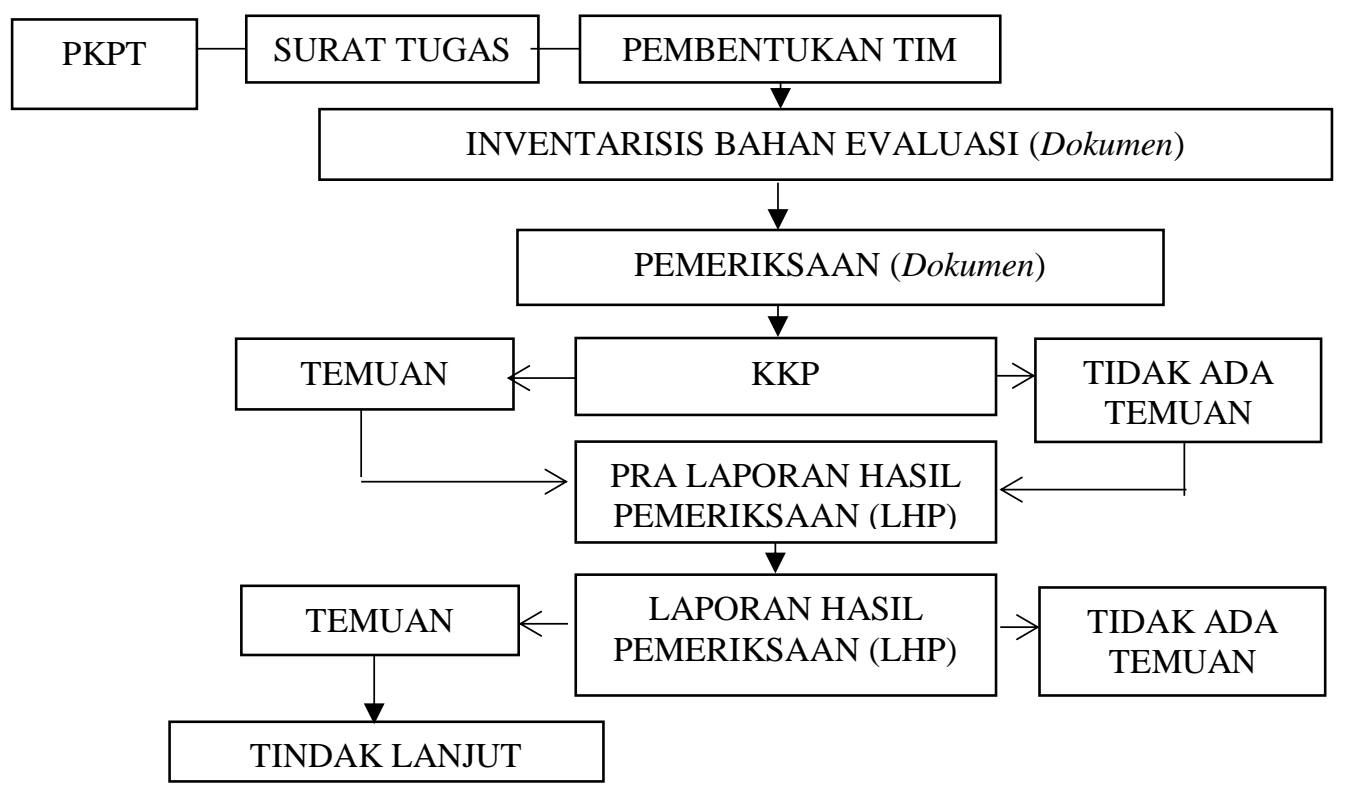

Gambar 1 diatas dapat dijelaskan bahwa prosedur pelaksanaan yang dilakukan oleh inspektorat kabupaten Batanghari diawali dengan kegiatan Penyusunan PKPT (Program Kerja Pengawasan Tahunan), dimana PKPT ini merupakan wujud dari pengaplikasian fungsi Inspektorat Daerah yang tercermin dalam Peraturan Bupati Nomor 28 Tahun 2018 Paragraf 1 Pasal 10 tentang kedudukan, Tugas dan Fungsi Sub Bagian Perencanaan yang menjadi tuntutan untuk dilaksanakan setiap tahunnya sebelum tahun anggatan dimulai dengan penyusunan Program Kerja Pengawasan Tahunan ( PKPT) yang merupakan wujud pengaplikasian fungsi Inspektorat yang tercermin dalam Pertuan Bupati ( PERBUP) Nomor 28 Tahun 2018 Paragraf 1 Pasal 10 tentang Keududukan, Tugas, dan Fungsi Sub Bagian Perencanaan yang menjadi tuntutan untuk dilaksanakan setiap tahunnya sebelum tahun anggaran dimulai. Selanjutnya dari PKPT tersebut dikeluarkanlah Surat Tugas bagi Auditor yang ditunjuk dengan prosedur pelaksanaan sebagai berikut : Pembentukan Tim, sesuai dengan Surat Perintah Tugas dari Kepala Inspektot yang berisikan Susunan Tim, Auditan, Ruang Lingkup Pengawasan, Waktu serta kewajiban yang dibebankan kepada Tim. Surat Perintah Tugas dikeluarkan bagi penanggan khusus dan umum. Tim yang sudah ditunjuk kemudian melakukan Inventarisasi Dokumen Bahan Evaluasi sebagai dasar memberitahukan objek pengawasan dimana pada pemberitahuan tersebut menyangkut Waktu, lamanya pemeriksaan dan nama yang ditugaskan, Pemberitahuan tersebut disampaikan 2 (dua) minggu sebelum tim turun kelapangan. Sesuai dengan Surat Tugas Prosedur selanjutnya tim melakukan pemeriksaan terhadap Dokumen yang sudah diinvetarisir melalui survey tahap awal yang meliputi : Data Permanen seperti peraturan-peraturan, struktur organisasi, uraian tugas, prosedur. Data Non Permanen Seperti data Keuangan, Kepegawaian, Invetaris Kantor. Setelah melakukan kegiatan pemeriksaan prosedur selanjutnya adalah menyusun Kertas Kerja Pemeriksaan (KKP), yang merupakan data dan catatan yang dikumpulkan secara sistematis oleh ketua Tim beserta anggota selama tugas pemeriksaan berlansung, Kertas Kerja tersebut harus mencerminkan langkahlangkah pemeriksaan yang dilakukan oleh tim, segala aktivitas yang dilakukan baik informasi yang diperoleh dan kesimpulan dituangkan dalam KKP, hasil kesimpulan dalam penyusunan KKP disampaikan dalam rapat tim untuk dievaluasi, apakah pemeriksaan tersebut ada temuan atau tidak ada temuan. Sebagai kegiatan akhir dari pemeriksaan adalah penyusunan Laporan Hasil Pemeriksaan (LHP) yang merupakan sarana komunikasi resmi tapi bersifat rahasia dan sangat penting dagi auditor untuk menyampaikan informasi tentang temuan, kesimpulan dan rekomendasi kepada auditan (objek) dan pihak yang perlu mengetahui tentang informasi tersebut. Apabila didalam LHP tersebut terdapat informasi ada temuan, maka rekomendasi yang dikeluarkan adalah auditan (objek) harus melakukan Tindak Lanjut (TL) yang diberikan waktu selama 60 (enam puluh hari), apabila dalam jangka waktu 60 (enam puluh hari) tersebut tidak ada tindak lanjut maka menjadi kewengan pihak Ekternal yaitu Kepolisian dan Kejaksaan.

\section{Perkembangan Temuan Pelaksanaan Pengawasan Pengelolaan Dana Desa pada Inspektorat Kabupaten Batang Hari}

Pengolahan Laporan Hasil Pemeriksaan dilakukan oleh Kasubag Evaluasi dan Pelaporan, dimana Subbag inilah yang merekap LHP sesuai dengan temuan masing-masing baik bagi temuan yang merugikan negara, temuan setoran pajak, temuan kedisiplinan dan teguran tertulis Rekapitulasi yang disusun dinamakan dengan Tindak Lanjut yang harus diselesaikan selama 60 ( enam puluh) hari sebelum laporan terbit. Semua ketentuan diatas berlaku untuk 
semua pemeriksaan termasuk terhadap pelaksanaan penggunaan Dana Desa. Selama tahun 2013-2017 temuan Dana Desa dikabupaten Batang Hari dapat dilihat pada Tabel 2.

Tabel 2

Temuan Pengawasan Pengelolan Dana Desa Kabupaten Batang Hari 2013-3017

\begin{tabular}{|c|c|c|c|c|c|c|c|}
\hline \multirow{2}{*}{ No } & \multirow{2}{*}{ Kecamatan } & \multicolumn{5}{|c|}{ Jumlah Temuan } & \multirow{2}{*}{ Total } \\
\hline & & 2013 & 2014 & 2015 & 2016 & 2017 & \\
\hline 1 & Muara Bulian & 7 & 2 & 8 & 2 & 2 & 21 \\
\hline 2 & Muaro Sebo Ulu & 9 & 11 & 12 & 1 & 2 & 35 \\
\hline 3 & Muara Tembesi & 10 & 5 & 10 & 2 & 1 & 28 \\
\hline 4 & Pemayung & 25 & 16 & 9 & 18 & 1 & 69 \\
\hline 5 & Bajubang & 4 & 3 & 5 & 10 & 4 & 26 \\
\hline 6 & Batin XXIV & 8 & 22 & 17 & 3 & 4 & 54 \\
\hline 7 & Mersam & 14 & 13 & 4 & 1 & 2 & 34 \\
\hline 8 & Maro Sebo Ilir & 6 & 2 & 14 & 1 & 9 & 32 \\
\hline \multicolumn{2}{|c|}{ Jumlah } & 83 & 74 & 79 & 38 & 25 & 299 \\
\hline \multicolumn{2}{|c|}{ Rata- Rata } & 10,38 & 9,25 & 9,88 & 4,75 & 2,88 & 37,38 \\
\hline \multicolumn{2}{|c|}{ Perkembangan } & 0 & $-10,89 \%$ & $6,81 \%$ & $-51,92 \%$ & $-39,37 \%$ & \\
\hline
\end{tabular}

Sumber : Inspektorat Kabupaten Batang Hari (Data Diolah)

Tabel 2 diatas terlihat bahwa selama tahun 2013 - 2017 kecamatan Pemayung tercatat sebagai kecamatan yang banyak mendapatkan temuan yaitu sejumlah 69 temuan, sedangkan kecamatan yang paling sedikit selama periode 2013-3017 adalah kecamatan Muara Bulian dengan jumlah temuan 21. Untuk perkembangan temuan selama periode 2013-2014 dapat dijelaskan sebagai berikut: pada tahun 2014 terjadi penurunan hasil temuan pengelolaan dana desa dikabupaten Batang Hari sebesar 10,89\% dari tahun sebelumnya (2013) tetapi pada tahun 2015 temuan pengawasan Dana Desa naik sebesar 6,81\% dari tahun sebelumnya sedangkan pada tahun 2016 dan 2017 temuan terhadap pemeriksaan Dana Desa dikabupaten Batang Hari mengalami penurunan masing-maing sebesar 51,92\% dan $39,37 \%$ hal ini menunjukan bahwa temuan Dana Desa di Kabupaten Batang Hari cenderung mengalami penurunan, artinya pengawasan yang dilakukan oleh Inspektorat Kabupaten Batang Hari sudah baik.

\section{Tingkat efektivitas Pelaksanaan Pengawasan Pengelolaan Dana Desa pada Inspektorat Kabupaten Batang Hari}

Tingkat Efektivitas Tindak Lanjut Dana Desa atas pelaksanaan pengawasan Inspektorat Kabupaten Batang Hari Tahun 2013-2017 dapat dilihat pada tabel berikut :

Tabel 2

Tingkat efektivitas Pelaksanaan Pengawasan Pengelolaan Dana Desa pada Inspektorat Kabupaten Batang Hari tahun 2013-2017

\begin{tabular}{|c|c|c|c|c|c|c|c|c|c|c|c|c|c|c|}
\hline \multirow{2}{*}{ No } & \multirow{2}{*}{ Kecamatan } & \multicolumn{2}{|c|}{2013} & \multicolumn{2}{|c|}{2014} & \multicolumn{2}{|c|}{2015} & \multicolumn{2}{|c|}{2016} & \multicolumn{2}{|c|}{2017} & \multicolumn{2}{|c|}{ Total } & \multirow{2}{*}{ Efektivitas } \\
\hline & & $\mathrm{T}$ & TL & $\mathrm{T}$ & TL & $\mathrm{T}$ & $\mathrm{TL}$ & $\mathrm{T}$ & $\mathrm{TL}$ & $\mathrm{T}$ & $\mathrm{TL}$ & $\mathrm{T}$ & $\mathrm{TL}$ & \\
\hline 1 & Ma. Bulian & 7 & 6 & 2 & 1 & 8 & 6 & 2 & 2 & 2 & 0 & 21 & 15 & $71,43 \%$ \\
\hline 2 & MSU & 9 & 6 & 11 & 8 & 12 & 8 & 1 & 1 & 2 & 2 & 35 & 25 & $71,43 \%$ \\
\hline 3 & Ma.Tembesi & 10 & 7 & 5 & 3 & 10 & 9 & 2 & 2 & 1 & 1 & 28 & 22 & $78,58 \%$ \\
\hline 4 & Pemayung & 25 & 18 & 16 & 11 & 9 & 9 & 18 & 12 & 1 & 1 & 69 & 51 & $73,92 \%$ \\
\hline 5 & Bajubang & 4 & 4 & 3 & 1 & 5 & 5 & 10 & 8 & 4 & 4 & 26 & 22 & $84,63 \%$ \\
\hline 6 & Batin XXIV & 8 & 7 & 22 & 16 & 17 & 8 & 3 & 1 & 4 & 0 & 54 & 32 & $59,26 \%$ \\
\hline 7 & Mersam & 14 & 10 & 13 & 9 & 4 & 1 & 1 & 1 & 2 & 2 & 34 & 23 & $67,69 \%$ \\
\hline \multirow[t]{3}{*}{8} & MSI & 6 & 4 & 2 & 1 & 14 & 9 & 1 & 1 & 9 & 3 & 32 & 18 & $56,25 \%$ \\
\hline & Jumlah & 83 & 62 & 74 & 50 & 79 & 55 & 38 & 28 & 25 & 13 & 299 & 208 & $69,57 \%$ \\
\hline & Efektivitas & & $70 \%$ & & $57 \%$ & & $62 \%$ & & $58 \%$ & & $00 \%$ & & $57 \%$ & \\
\hline
\end{tabular}

Sumber : Inspektorat Kabupaten Batang Hari (Data Diolah)

Tabel 2 diatas dapat dijelaskan tingkat efektvitas pelaksanaan pengawasan Pengelolaan Dana Desa pada Inspektorat Kabupaten Batang Hari selama tahun 2013 - 2017 untuk masing-masing kecamatan sebagai berikut ; Kecamatan Muara Bulian total 15 Tindak Lanjut (TL) dari 21 Temuan (T) dengan rasio efektivitasnya sebesar 71,43\%, ini menunjukan bahwa tingkat capaian pada Kecamatan Muara Bulian Cukup Efektif, sama halnya dengan kecamatan Masro Sebo Ulu dengan Rasio Efektivitas 71,43\% menunjukkan capaian yang Cukup Efektif. Sedangkan Kecamatan Muara Tembesi dengan Rasio 78,58 \% menunjukkan bahwa Pelaksanaan Pengawasan Dana Desa di Kecamatan Muara Tembesi Cukup Efektif. Untuk kecamatan Pemayung dengan Rasio efektifitas 73,92\% artinya Pelaksanaan Pengawasan Dana Desa di kecamatan tersebut cukup efektif. Dari hasil analisis yang dilakukan tingkat rasio terbesar terdapat pada kecamatan Bajubang yaitu sebesar 84,63\% artinya capaian pelaksanaan pengawasan yang 
dilakukan di Kecamatan Bajubang Sangat Efektif. Pelaksanaan Pengawasan Dana Desa di kecamatan Batin XXIV capaiannya Tidak Efektif terlihat dari rasio efektifitasnya pada angka 59,26\%. Sedangkan Kecamatan Mersam Pelaksanaan Pengawasan Dana Desa yang dilakukan oleh Inspektorat Cukup efektif dengan rasio 67,69\%. Pelaksanaan Pengawasan Dana Desa di Kecamatan Maro Sebo Ilir Tidak Efektif terlihat rasio efektivitasnya sangat kecil dibandingkan dengan kecamatan yang lain yaitu 69,57\%. Selanjutnya dari tabel diatas Tingkat efektivitas Pelaksanaan Pengawasan Dana Desa yang dilakukan oleh Inspektorat Kabupaten Batang Hari 2013 - 2016 sudah dilakukan secara Cukup Efektif, terlihat dari angka rasio pada tahun 2013 yaitu 74,70\%, tahun 2014 sebesar 67,57\% dan pada tahun 2015 sebesar 69,62\% begitu juga pada tahun 2016 rasio efektifitasnya menunjukkan angka 73,68\%, sedangkan pada tahun 2017 Pelaksanaan Pengawasan Dana Desa yang dilakukan oleh Inspektorat Kabupaten Batanghari Tidak Efektif terlihat dari rasio efektifitasnya sebesar 52,00\%. Tetapi dari Pelaksanaan Pengawasan Dana Desa yang dilakukan oleh Inspektorat rata - rata selama tahun 2013-2017 menunjukkan capaian Cukup Efektif dengan rasio efektiftasnya sebesar $69,57 \%$.

\section{SIMPULAN}

Prosedur Pelaksanaan Pegawasan yang dilakukan oleh inspektorat kabupaten Batanghari diawali dengan kegiatan Penyusunan PKPT (Program Kerja Pengawasan Tahunan) dilanjutkan dengan Penyusunan Laporan Hasil Pemeriksaan, serta penyampaian hasil temuan sampai dengan pelaksanaan Tindak Lanjut. Perkembangan temuan pelaksaan pengawasan Dana Desa pada Inspektorat Kabupaten Batang Hari selama tahun 2013-2017 didapat bahwa kecamatan Pemayung tercatat sebagai kecamatan yang banyak mendapatkan temuan yaitu sejumlah 69 temuan, sedangkan kecamatan yang paling sedikit selama periode 2013-3017 adalah kecamatan Muara Bulian dengan jumlah 21 temuan. Perkembangan temuan terbesar pada tahun 2017 yaitu meningkat sebesar 6,81\% dari temuan tahun sebelumnya kemudian pada tahun 2016 dan 2017 terjadi penurunan secara signifikan yaitu turun sebesar 51,92\% (2016) dan pada tahun turun 39,37\% dari tahun sebelumnya secara umum menunjukan bahwa temuan Dana Desa di Kabupaten Batang Hari selama tahun 2013-2017 cenderung mengalami penurunan, artinya pengawasan yang dilakukan oleh Inspektorat Kabupaten Batang Hari sudah baik. Pelaksanaan Pengawasan Dana Desa yang dilakukan oleh Inspektorat rata-rata selama tahun 2013-2017 menunjukkan capaian Cukup Efektif dengan rasio efektiftasnya sebesar $69,57 \%$.

\section{DAFTAR PUSTAKA}

Abdul Halim, 2004. Manajemen Keuangan Daerah, Edisi Revisi , Yogyakarta : UPP AMP

Aprillia, 2014. Pembangunan Berbasis Masyarakat, Bandung : Alfabeta

Arif, Muhammad. 2007. Tata Cara Pengelolaan Keuangan Dana Desa Dan Pengelolaan Kekayaan Desa. Pekanbaru,ReD Press.

Beratha, I Nyoman, 1992 . Masyarakat Desa dan Pembangunan Desa. Jakarta : Ghalia Indonesia.

Bratakusumah Deddy Supriady, Dadang Solihin, 2002, Otonomi Penyelenggaraan Pemerintahan Daerah, Jakarta, PT Gramedia Pustaka Utama.

Effendi Bachtiar ,2002. Pembangunan Desa Berwawasan Lingkungan . Jakarta : Bumi Aksara.

Huda Ni'matul, 2007. Pengawasan Pusat Terhadap Daerah Dalam Penyelengaraan Pemerintahan Daerah, FH UII Press, Yogyakarta.

Hanif, Nurcholis 2011, Pertumbuhan dan Penyelenggaraan Pemerintah Desa, Jakarta Erlangga.

Manullang, M 2012, Manajemen Sumber Daya Manusia, Ghalila Indonesia. Jakarta

Nurcholis. 2011, Pertumbuhan dan Penyelenggaraan Pemerintah Desa. Jakarta, Erlangga.

Peraturan pemerintah Nomor 79 Tahun 2005 tentang pedoman pembinaan dan pengawasan penyelenggaraan pemerintahan daerah memuat kedudukan yang terkait dengan inspektorat Provinsi maupun inspektorat kabupaten/kota

Peraturan Pemerintah Nomor 47 Tahun 2015 tentang perubahan atas Peraturan Pemerintah Nomor 43 Tahun 2014 Tentang Peraturan Pelaksana Undang-Undang Desa

Peraturan Pemerintah Nomor 22 Tahun 2015 tentang Perubahan atas Peraturan Pemerintah Nomor 60 Tahun 2014 Tentang Dana Desa

Permendesa Nomor 8 Tahun 2016 perubahan Nomor 21 Tahun 2015 tentang Penetapan Prioritas Penggunan Dana Desa.

Soemantri, 2011. Pedoman Penyelenggara Pemerintah Desa, Bandung : Fokus Media

Triwibowo Arief ,2016. Dari Mahasiswa Untuk Desa, Bandar Lampung,

Undang-Undang Nomor 15 Tahun 2004, Tentang Pemeriksaan Pengelolaan dan Tanggung Jawab Keuangan Negara. 